\title{
ROLE OF KNOWLEDGE IN INFORMATION SOCIETY
}

\author{
Jelena Vukašinović \\ Singidunum University, Serbia
}

\begin{abstract}
:
Development of information technologies and activities, which are largely associated with information technologies, has led to the fact that many advanced countries in the world declared as information societies, and thus along with the increased number of countries that declared themselves, a term information age was created. The term information society describes a social system in which production and services largely depend on information technologies, and on understanding of knowledge as a key resource of organizations. This paper is aimed at showing the role of knowledge in information society and pointing at changes that consequently occurred in the educational system.
\end{abstract}

\section{Key words:}

knowledge,

soft skills,

information society,

knowledge workers.

\section{INTRODUCTION}

Unlike industrial society, which implied the use of manual and physical skills of workers in processes of creation of products and services, the information society is based on computer technologies which rely on the knowledge of workers understood in terms of dialectic unity of professional and personal skills. All this is with an aim to create knowledge-workers who, according to Drucker, are individuals who use knowledge as tools, as an efficient process applicable and directed towards the results, who confirm and further develop themselves in practice, since soft skills are precisely those which determine the manner in which individuals apply their professional and practical knowledge as a tool and use information technologies and foreign languages.

\section{INFORMATION SOCIETY AS KNOWLEDGE SOCIETY}

Information society presupposes changes in application and understanding of information and communication technologies and knowledge which, with the central role in new economy, makes influence on the work process, employees and their attitude to work, but also on society as a whole. Therefore, a need arose for the innovativeness in daily business activities, but always in a faster manner than competition. Consequently, the information society presupposes the environment which nourishes creativity and innovativeness, and is based on knowledge and constant learning and acquiring of hard and soft skills, which is a premise of modern knowledge tions, which are always focused on new and creative application of knowledge that will lead to the creation of an added value. This is particularly the reason why knowledge in information society has been determined by the following presumptions:

1) There are increasingly more jobs which require a high level of knowledge of information and communication technologies and skills needed for their application,

2) The necessity of constant innovation, in accordance with ever new demands of technology, which creates an obligation to involve in the process of production or provision of services not only of the employees and their managers, but beneficiaries of services and customers also,

3) Combining and connecting hard skills and soft skills, by applying information and communication technologies in order to approach any problem from many aspects and thus maximize the value of intellectual capital,

4) The necessity that employees are turned to their potentials and accordingly to adjust, organize and balance their lives.

The above stated imposes an obligation on all participants in information society to understand the necessity of adoption, development and constant improvement of knowledge and development of soft skills that will enable them to be adaptable to changes in the environment, to be ready for emergence of new industries and new occupations that will transform their view at world, and make them open for new knowledge that will increase their productivity in modern economy based on knowledge, by applying information and communication technologies. 


\section{EDUCATIONAL SYSTEM IN INFORMATION SOCIETY}

The development of information and communication technologies, which enables exchange of information, convergence of digital technologies, increasing use of Internet and opening of telecommunication markets, in the early nineties of the last century led to the change in educational system, particularly in new opportunities for transmitting and adopting the knowledge through remote and e-learning. The changes that consequently occurred at the global level, which include educational systems, had a decisive impact on their functioning, and thus new education goals were defined in the world, in line with economic, social, cultural and ideological changes, as it was realized that ability of society to produce, choose, adjust, commercialize and use knowledge became crucial for sustainable economic growth and increase of living standard. Knowledge thus became the most important thing of economic development:[1]

One of the reasons for increasing the value of knowledge is certainly the establishment of the unique world labour market, which is also the consequence of globalization, development of communication and reduction of transportation costs. If we add political opening of borders, we become aware that individuals with right education in the unique labour market have the greatest value. [2] And that is precisely why in XXI century, the rich countries are competing to attract and keep the best "brain" in the world in different ways. The most important measures are politics, which stimulates the scientific and research activities, and direct investments, attractive offers for post-graduate programmes and research and recruitment of students and young professionals. [3]

Along with changes that occurred, over the past two decades many countries have experienced the expansion in education, which came as a response to the need to respond to market demands. There emerged also different types of educational institutions in addition to traditional universities, precisely technical institutes and public colleges, polytechnic academies, distance learning centres and open universities. In the countries of Latin America, Asia and recently in the countries of Eastern Europe and Sub-Saharan Africa, the number of educational institutions has particularly increased. [4]

The next wave of adapting the education to global changes came with the strategic change in thinking of educational institutions in which they now want to become competitive, and thus virtual universities, franchised universities, corporative universities, media houses, libraries, museums and other institutions emerge by breaking institutional and geographical borders and start dealing with education being the educators either independently or in teams.[5] In addition to these institutions, software developers, publishers, entertainment companies, and others, also appeared in education sector with an aim to take part in the unique international field of education[6], offering the response to changes that arose with the emergence of knowledge-based economy.
Precisely for this reason, and following the expansion of different educational institutions, many countries did introduce strict accreditation rules that should have ensure the quality of educational system, taking thereby care about the needs of market and economy that was going through its own transition towards the knowledge-based economy.

In addition to the above stated, developed countries also experienced that large companies today have their own universities, scientific and research laboratories and institutes, in order to ensure the quality of staff, but also to shorten the time needed to elapse from the idea to the realization, and time of training of employees. Since 1990, when there were 400 of them, their number has been constantly growing and now it is more than 1,000. The examples of such companies are Dell and IBM, which apply information technologies in education by using eLearning platforms, or the hotel Ritz Carlton which organizes daily "line of quality" in every shift, where employees have an opportunity to become familiar with instructions for achieving the required quality of services. The company Motorola is also known for its great investments in education and training of employees. The benefits of trainings in the field of quality are multiply greater than costs of training, the ratio being even 30 to 1 . American company Xerox, which is known in the world for its utmost effective organization, invests over 125 million American dollars in trainings of its employees. The employees in Honda, a Japanese producer of cars, engines, trucks, robots and other equipment, regularly use interactive computer trainings for upgrading the process of production. However, the employees working in sales and service departments spend about five weeks at trainings in order to get trained for as better as possible communication with consumerscustomers. [7]

All these changes that followed actually indicated the need to increase the flexibility of educational systems and to establish educational institutions which can respond to market demands in the right way and at right time. The changes related both to restructuring of study programmes and the change of the very structure of institutions and their organizations, pedagogical work and to the change in form of knowledge transfer and other education processes. Many of these changes were carried out thanks to the application of information technologies, which became teaching and pedagogical resources that enable that information is transmitted and shared easily, as well as administrative tools that contributed to efficiency and reduction of costs of running these institutions. However, with the transition from elite to mass educational system and with introduction of educational system focused on learning and not mere transmitting of facts, a student became a more significant participant, as a primary client, beneficiary of service and future employee who should work in knowledge-based economy. All these required adjustment and development of traditional educational institutions, which suddenly gained the role of service for "production of quality base" that will give rise to knowledge workers. 


\section{APPLICATION OF INFORMATION}

\section{TECHNOLOGIES IN EDUCATIONAL SYSTEM}

The application of modern information and communication technologies in the educational system requires the introduction of new pedagogical methods, which primarily imply the use of modern information systems, multimedia, computer and Internet, which enable that lectures are not the mere transmitting of facts but an activity of a lecturer and interactivity in learning.

In addition, it is necessary to introduce the wide application of educational methods, which already exist in practice and have so far given extraordinary methods applied in Waldrof and Montesori systems of education. According to the research, which Kozma and Johanson have conducted by analyzing different models in which information technologies may help realize the instructional process, new pedagogical methods should actively engage students in the instructional process rather than let them be just mere recipients of information. Further on, Kozma and Johanson point out that students should be enabled to apply their knowledge to real life situations, and presenting of knowledge should be conceptually changed from textual transmitting of information to interactive multimedia presentations. What seems to be the most important in the system in which knowledge should be created is learning as a collective act and not an individual act of students, as their active participation in the learning process and not mere memorizing of information. In order for this process of education to be carried out, it is necessary, at the level of elementary school, to develop an ability of students to be active in the learning process and motivated to learn through the life even more and thus the goals of concept of lifelong learning will be achieved, being the key one in information society and knowledge-based economy.

\section{INFORMATION SOCIETY AS SOCIETY OF KNOWLEDGE-WORKERS}

If educational programmes are in accordance with needs of economy and if modern teaching methods are used, with a student being the centre of learning, the result is an educated professional that can easily adapt to all business processes regardless of the area of work, since this will provide graduate students with theoretical and professional basis, which implies the possession of modern theoretical and practical knowledge, knowledge of IT technologies and foreign languages, which together may be called hard skills, and the student will have all other knowledge and skills needed to find their place in the future labour market, as knowledge-workers in information society.

The most important contribution of the previous system of education is reflected in creation of workers able to contribute to increasing the value of organizations though manual work, while the greatest contribution of education in economy of XXI century will certainly be contributing to creation of one entirely new generation of workers, knowledge-workers who, according to findings of this re- search, will be the greatest production resource, who, on the other hand, are both the presupposition and result of information society or knowledge society.

Knowledge-workers are constantly pushing the boundaries between work and learning, and their main characteristic is constant updating of knowledge, as well as acquiring of new professional skills with soft skills being predominant. However, the development of knowledge-workers is only in its infancy and educational systems need yet to adjust to market demands and develop efficient models for education of knowledge-workers by applying modern information and communication technologies. According to Drucker, there are six major factors which determine the productivity of knowledge workers :

1) Productivity of knowledge-workers requires asking the questions: "What is the task";

2) Productivity depends on how much the organization is willing to give responsibility to knowledgeworker. Knowledge-workers need to have skills by which they will know how to manage themselves, their time in the autonomy they have,

3) Continuing innovation has to be part of the work, the task and the responsibility of knowledge workers,

4) Knowledge-workers require continuous learning in the respective field of work, but they also have a constant need to transfer their knowledge to others,

5) Productivity of knowledge-workers is not primarily a matter of quantity but rather a matter of quality of output,

6) Finally, productivity of knowledge-workers depends on whether the organization treat them as a cost or as an asset, which means that knowledgeworkers want to work for that organization over all other opportunities.

The response to these characteristics of knowledgeworkers is in soft skills and application of modern information and communication technologies, since those are the skills that will enable the knowledge-worker to show all his/her potential through productive imagination, and the task of the educational system is to provide the individuals of all ages with the knowledge and skills that will result in the above stated. [8]

\section{CONCLUSION}

On the basis of the above stated, we can conclude that one of key changes that information society rendered is exactly the change in understanding of knowledge, both at the level of its structure and its transmitting in the educational system. Since the basic purpose of high education is to educate the staff which possesses competences and knowledge required by economy, it is of crucial importance that high education with its study programmes responds to requirements of economy, both in terms of contents, by enabling the students to acquire soft and hard skills, and in terms of methods of work. The question remains as to how this change is manifested in real environ- 
ment, and how the changes needed in educational system be carried out, with an aim to create a knowledge-worker.

\section{LITERATURA}

[1] Abeles, T., "The Academy in a Wired World", Futures 30 (7): 1998, pages 603-13.

[2] Carrington, William J., Enrica Detragiache, „How Extensive is the Brain Drain?", Finance \& Development 36 (June), 1999, pages 46-49

[3] Glanz, James, "Trolling for Brains in International Waters", New York Times, (April 1), 2001.

[4] "Constructing Knowledge Societies: New Challenges for Tertiary Education", The International Bank for Reconstruction and Development / The World Bank, available at http://www.mpn.gov.rs/resursi/dokumenti/dok220-engWB_ConstructingKnowledgeSocieties.pdf, pages 32-33
[5] Salmi, Jamil, "Student Loans in an International Perspective: The World Bank Experience", LCSHD Paper Series 44. World Bank, Washington, D.C. , 2000, available at www. wbln0018.worldbank.org/LAC/lacinfoclient.nsf/d2968495 1174975c85256735007fef12/d4a6119794fde8be852567920 06c55cb?OpenDocument

[6] Bennell, Paul, Terry Pearce, “The Internationalisation of Higher Education: Exporting Education to Developing and Transitional Economies”, IDS Working Paper 75. Brighton, U.K.: Institute of Development Studies, University of Susse, 1998

[7] Stanković, Vladimir, "Education and training of employees”, seminar paper, 2011, page 17, available at http://www. its.edu.rs/cms/mestoZaUploadFajlove/ObrazovanjeIObukaZaposlenihStankovic240v9.pdf

[8] Vukašinović, Jelena," The role of business skills in raising competitive advantage of organizations within service industry”, PhD theses, University Singidunum, 2014, str. 350. 